\title{
A Dramaturgical Study of Merrythought's Songs in The Knight of the Burning Pestle
}

'Let him stay at home and sing for his dinner', advises Mistress Merrythought about her highly musical husband, Old Merrythought, who believes in achieving mirth and health through much singing, a good portion of which has the pretext of conviviality, in particular, drinking. ${ }^{1}$ The philosophy embedded in Old Merrythought's sundry songs in Francis Beaumont's The Knight of the Burning Pestle (c 1607) $)^{2}$ shows the coexistence of orderliness and disorderliness related to music, a duality pervasive in the use of music in English Renaissance drama. Early modern English culture attached a wide range of associations to music; various pairs of ideological dichotomies can be identified, such as sublimation and corruption of the soul, love and lust, masculinity and femininity, and destruction and restoration of sanity. ${ }^{3}$ In this essay, I first provide a brief contextual background of the perception and practice of music, and illustrate with a few episodes from Elizabethan and Jacobean plays the diversity of connotations carried by music as well as how music can be incorporated into various types of dramatic scenarios. ${ }^{4}$ These examples reflect the general musical landscape of Renaissance drama. I then evaluate the dramaturgical characteristics of Merrythought's songs in relation to the contemporary cultural and dramatic milieux.

\section{Views on Music}

The negotiation between the divine and the corrupting in music has always been an important part of the social and philosophical understanding of the art since classical times. Plato states in The Republic that one should not indulge in too much music lest the soul become bewitched and weak:

So if you give music the chance to play upon your soul, and pour into the funnel of your ears the sweet, soft, lamenting modes ... if you spend your whole life 
humming them, bewitched by song, then the first effect on a nature with any spirit in it is to soften it, like heating iron, making it malleable instead of brittle and unworkable. But if you press on regardless, and are seduced by it, the next stage is melting and turning to liquid - the complete dissolution of the spirit. It cuts the sinews out of your soul, and turns it into a "feeble warrior"... . People like this become hot-tempered and quick to anger, irritable instead of spirited. ${ }^{5}$

Similarly, while music is considered to be one of the four 'customary branches of education' in The Politics, Aristotle speaks of the benefits of enjoying music in moderation. ${ }^{6}$ In the sixth century, Boethius also thinks that music has direct effect and affect upon the internal harmony of its listeners: 'Nothing is more characteristic of human nature than to be soothed by sweet modes and disturbed by their opposites'. The Roman philosopher regards the effect of music as dependent on both the listeners and the music itself: 'A lascivious mind takes pleasure in the more lascivious modes ... Contrariwise, a sterner mind either finds joy in the more stirring modes and is braced by them'. ${ }^{7}$ Saint Isidore of Seville, some 100 years later, praises music unreservedly in Etymologiarum:

Thus without music no discipline can be perfect, for there is nothing without it. The very universe, it is said, is held together by a certain harmony of sounds, and the heavens themselves are made to revolve by the modulation of harmony. ${ }^{8}$

Gioseffo Zarlino, a Renaissance music theorist, takes up this notion in Institutioni harmoniche. Zarlino affirms that 'there is no good thing that does not have a musical disposition', and is convinced that music 'leads man back to the contemplation of celestial things and has such power that it perfects everything it is joined to? ${ }^{?}$

Boethius's idea that the same piece of music can produce different effects in different listeners finds echo in Thomas Wright's The Passions of the Minde. Wright writes about different interactive perceptions of any musical episode:

divers consorts stirre up in the heart, divers sorts of joyes, and divers sorts of sadnesse or paine: the which as men are affected, may be diversely applyed: Let a good and a godly man heare musicke, and he will lift up his heart to heaven: let a bad man heare the same, and hee will convert it to lust ... True it is, that one kinde of musicke may be more apt to one passion then another. ${ }^{10}$ 
Wright takes a less defined stance than many others of his time. He is aware of the two distinct types of reactions music can arouse in the hearers' souls, the sublimating and the corrupting, and the action of music is here presented as dependent on the individual temperament of the perceiver. Similar reasoning can be found in The Praise of Musicke, which asserts that it is not at all the fault of music if one is found to be moved by it to effeminate or wanton thoughts, because music 'it selfe is good: but [the fault is] in the corrupt nature, and evil disposition of light persons, which of themselves are prone to wantonnes'. 11

A number of Wright's contemporaries, however, are not as tolerant. Music to them is either good or bad; there is no intermediary stance. William Byrd, not surprisingly, has a generally positive outlook on music. In Psalmes, Sonets, or Songs of Sadnes and Pietie, he catalogues reasons (although some of them are rather pedestrian) as to why one should learn to sing, and concludes that 'Since singing is so good a thing, / I wish all men would learne to sing'.12 Singing was meant to be common for everyone in Elizabethan England. As F.W. Sternfeld writes, paraphrasing Thomas Morley, 'the art of singing was cultivated with equal zeal and discernment in every grade of social rank' ${ }^{13}$ Such inclination, however, often found constraint in contemporary society since it was deemed inappropriate for aristocrats or gentlefolks to either sing or play musical instruments in public, as is made clear by Henry Peacham: 'I desire no more in you than to sing your part sure, and at the first sight, withall, to play the same upon your Violl, or the exercise of the Lute, privately to your selfe' (my emphasis). ${ }^{14}$ Society expected a distinction to be maintained between members of the nobility and their music-providing attendants.

Benefits in music, however, can be overridden by anxieties about the possible detrimental effects it may cause. Puritan writer Philip Stubbes, for example, denounces music in Anatomy of Abuses. He accuses it of contaminating young girls' minds: 'if you would have your daughter whorish, bawdy, and uncleane, and a filthy speaker, and such like, bring her up in musicke and dauncing'. Regarding the upbringing of boys, he writes:

If you would have your sonne soft, womannish, uncleane, smooth mouthed, affected to bawdry, scurrility, filthy rimes, and unseemly talking: briefly, if you wold have him, as it were transnatured into a woman, or worse, and inclined to all kind of whordome and abhomination, set him to dauncing schoole, and to learn Musicke, and then shall you not faile your purpose. ${ }^{15}$ 
This view of the unwholesomeness of music extends to criticism of music used in theatrical performances. According to Stephen Gosson, the 'sweete confortes in Theatres ... rather effeminate the minde, as prickes unto vice, then procure amendment of maners as spurres to vertue'. ${ }^{16}$

Individuals who attack music on the grounds that this form of art demoralizes the soul only see one aspect of what music can do to our minds, and magnify it alarmingly. Likewise, those who write profusely about the benefits one can obtain from practising or listening to music might also have overlooked the possible dangers of certain types or manners of musical practice or performance. ${ }^{17}$ This is why Thomas Wright's view regarding both the positives and negatives generated from musical participation is more inclusive: it actually speaks to the universal construction of perspectives of music in the Renaissance - music as divine and music as damning. Such divarication makes music an essential and versatile dramatic device on the Renaissance stage.

\section{Some Musical Episodes from Elizabethan and Jacobean Drama}

The primary duality in music is best expressed in the title character Delphia from John Fletcher and Philip Massinger's The Prophetess (1622), ${ }^{18}$ who has the power to invoke preternatural music, both divine (2.3.43-52) and diabolical (3.2.105-9); heaven and hell are within the reach of and subject to the power of the prophetess's music. Florimell, a virgin from Fletcher and William Rowley's The Maid in the Mill (1623), ${ }^{19}$ sings five increasingly lascivious songs in an attempt to feign wantonness and to escape sexual assault by her kidnapper Otrante. She curbs his sexual desire for her by seducing him and making blatantly erotic references in her licentious songs accompanied with equally lewd dances and speeches. By the end of her songs, Otrante exclaims, 'She is either a damnd divel, or an Angel' (5.2.123); his assessment highlights the binary qualities associated with music. ${ }^{20}$

Music in Fletcher's tragedy Valentinian (c 1614) ${ }^{21}$ serves a number of purposes: seduction, assertion of masculinity, pacification, ceremony. The emperor Valentinian lusts after Lucina, a married woman who values her honesty highly and will not be moved by any amount of riches or fame. The king, who is regarded by his soldiers as 'too sensuall' and wenching too much (1.3.133), has his men put together an alluring display that involves music, perfumes, and jewels, hoping to stir Lucina into a wanton mood. Lucina, however, is not at all impressed with any of these sensory temptations. She 
finds none of the jewels shown 'worth halfe [her] honesty' (2.5.86) and deems the songs 'lascivious, / And over-light for Ladies' (2.5.51-2). Of the two songs sung for Lucina, the first, 'Now the lusty Spring is seene' (2.5.5-24), is a seductive song charged with sexual innuendos, and the second, 'Heare ye Ladies that despise' (2.5.25-44), speaks of 'mighty love' (2.5.26). Neither lust nor love interests Lucina. Similar episodes in which seductive music is rejected by its target audience include Volpone's 'Come, my Celia' (3.7.16582) in Ben Jonson's Volpone (c 1606), 22 and the accident-prone Monsieur Thomas's inappropriate fragments of ballads which are too ludicrous to bring about any successful seduction in Fletcher's Monsieur Thomas (c 1611).23 On the other hand, when appropriately administered, musical seduction can be successful: Malroda falls in love with Piorato's music 'most abominably' (3.2.108) in Fletcher's Love's Cure (c 1606); ;4 Donusa, a noble lady in Massinger's The Renegado $(1624)^{25}$ who desires haberdasher Vitelli, prepares a full-blown musical seduction scene for him (2.4) and subsequently lures him into her chamber.

Apart from songs of seduction which are meant to arouse amorous emotions, Valentinian also contains references to music specific to masculinity. Captain Pontius says that his songs

Goe not to'th Lute, or Violl, but to'th Trumpet,

My tune kept on a Target, and my subject

The well struck wounds of men, not love, or women.

Viols and lutes are regarded as instruments generating soft and effeminizing music. ${ }^{26}$ Fondness for soft music is unacceptable for men of military valour. Tamburlaine in Christopher Marlowe's 2 Tamburlaine the Great (c 1588)27 questions if his sons are 'too dainty for the wars' since they have fingers 'made to quaver on a lute', doubting whether they are of his own issue (1.3.28-9). Agamemnon in Thomas Heywood's 2 Iron Age (c 1612) ${ }^{28}$ finds it impossible for a great warrior, Achilles, to 'touch a womanish lute, / And hear the grones of twenty thousand soules / Gasping their last breath' (3.1.316-8). The importance of staying away from effeminizing soft music has a long history. Plato drew a distinction between musical modes — Dorian and Phrygian 'which can most fittingly imitate the voice and accents of a brave man in time of war' and thus are suitable for 'men of a warlike disposition', and modes which are appropriate for luxury, laziness, and parties (Ionian and Lydian). ${ }^{29}$ Lodowick Lloyd states that 'Mars claymed Musicke in the fielde, ... Venus 
occupieth Musicke in chambers. That kind of gentle and soft Musick, the Egyptians forbade the youth to be taught therin, least from men, they would become againe women'. ${ }^{30}$

Music is played to ease Valentinian's pain when he lies poisoned on his bed: 'The soft Musick; / And let one sing to fasten sleep upon him' (5.2.4-5). The song 'Care charming sleep, thou easer of all woes' (5.2.13-22) is about calling the power of slumber to 'fall like a Cloud' on the 'afflicted Prince' and to 'kisse him into slumbers like a Bride' $(5.2 .15,22)$. The gentle song eventually kisses Valentinian into an eternal sleep as the poisoned king is already 'Beyond all cure' (5.2.8). With the collapse of Valentinian, Maximus is hailed as the new king by his soldiers. Music is called for at the inauguration banquet of the new emperor: 'By any meanes some songs: but very short ones, / And honest language ... without bursting' (5.5.10-11). The men making arrangements for the banquet are looking for songs that are appropriate for a royal gathering. Two songs are prepared for the new king's investiture: the first, 'Honour that is ever living' (5.8.15-26), honours and praises the new Caesar, and the second, 'God Lyeus ever young' (5.8.37-46), is a drinking song. The irony of this musical episode is that while the drinking song appears to be present simply to enhance the festive spirit at the banquet, it also dishonours the feast since it allows time to let the poison on the wreath work its way to Maximus's death. The deadly wreath, which is brought in at the beginning of the banquet - 'With a Banket prepard, with Hoboies, Musicke, Song, wreath' (5.8. sd 1$)^{31}$ — is prepared by Queen Eudoxa, who deems her new husband not 'worth being Cesar' (5.8.99). The baneful wreath is probably already laid on Maximus's head by the end of the first song as this crowning action will then coincide with the last line of the first song, 'Bind this wreath with thousand vows' (5.8.26). The second song (the drinking song) therefore operates as a festive item and a dirge simultaneously. The paradox in this song is a striking parallel to what Eudoxa says of the wreath: 'That wreath that made him Cesar, / Has made him earth' (5.8.63-4).

In contrast with the sinister nuance in the music during Maximus's coronation, many theatrical events involve beneficial music. Music is often requested by characters suffering from different degrees of malaise. In Jonson's Poetaster (c 1601), ${ }^{32}$ for example, Ovid and his fellow gods are feeling bored in their gathering. One of them calls for some music to 'startle [their] spirits with a song' (4.5.159). The first song, 'Wake, our mirth begins to die, / Quicken it with tunes and wine' (4.5.176-83), probably has a rather grave tone since Ovid does not approve of it. He demands some 'louder musicke' to revitalize 
their senses (4.5.186-7), and thus a second song of 'a free and lofty straine' is sung, which is most likely to be much more lively as the singers are 'Running division on panting air' (4.5.191). Shakespeare's Pericles (c 1607) gives us a striking example of revitalizing the dying with music. ${ }^{33}$ Cerimon brings the moribund Thaisa back to life through a dose of music:

The rough and woeful music that we have,

Cause it to sound, beseech you.

The [vial] once more - how thou stirr'st thou block!

The music there. I pray you give her air.

Cerimon specifies rough and woeful music to be played to facilitate his 'operation'. While it is possible to present the music in this scene in a rough and woeful manner as stipulated, it is equally possible to see it another way. The music is described as 'rough' in all early printed texts of the play, but two Arden editors take different views of this reading. F.D. Hoeniger, for Arden 2, completely rejected it, stating that '"rough" is manifestly wrong', and adopted the reading 'still' first proposed in Maxwell's 1956 Cambridge edition. ${ }^{34}$ Suzanne Gossett, in Arden 3, however, accepts the quarto reading although she does support the 'frequent emendation to "still" music'. ${ }^{35}$

The word 'rough' is certainly not void of potential significance. Cerimon reads from the note in Thaisa's coffin about how rough the people were who 'threw [Thaisa] in the sea' (3.2.82), and so he tries to abate the prior roughness — rough sea, rough disposal, rough 'death' — with more roughness. Rough music is of a higher level of volume and often carries a stronger rhythm. According to the analogy made by Renaissance thinkers, strong rhythm and strong beat can lead to a strong heart beat. ${ }^{36}$ The application of curative music, be it rough or still, is further evidenced by a difference in spelling. Cerimon calls for 'The Violl once more' in Q1 and 'The Viall once more' in texts from Q4 onwards. ${ }^{37}$ 'Violl', or 'viol', is a variant spelling of 'vial', and many editions interpret the 'Violl' in Q1 as its homophonic 'vial', a piece of medical apparatus. ${ }^{38}$ But 'viol' also refers to a six-stringed instrument. With 'Violl' or 'Viall', this play insinuates the combination of medical and musical cures, drawing on the close association of music and medicine in Renaissance culture.

Indeed, many of the episodes involving curative music in Renaissance drama call upon music's medicinal effect, especially for treatment of lovesickness or love-related madness. Music as a therapy for a mind suffering from 
lovesickness is a concept that has existed throughout history, with much of the thinking originating in connection with the mythological figure of Orpheus. Physicians, philosophers, writers, and churchmen from the ancient GrecoRoman world wrote on the correlation between body, mind, and spirit in cases of love melancholy, which was already a medically established idea from the era of Hippocrates. ${ }^{39}$ Theophrastus was among the earliest philosophers to prescribe listening to harmonious music as a remedy for lovers troubled by melancholy, ${ }^{40}$ although one has to beware of possible counteractive effects from overdosing, a warning given by Avicenna. ${ }^{41} \mathrm{~A}$ similar undertone of concern can also be found in some of the medieval and Renaissance treatises that addressed musical cures for lovesickness, of which Robert Burton's is one of the most prominent. He sees much in music:

[Musicke] is so powerfull a thing, that it ravisheth the soule, regina sensuum, the Queene of the sences, by sweet pleasure, (which is an happy cure) and corporall tunes pacifie our incorporeall soule, sine ore loquens, dominatum in animam exercet, and carries it beyond it selfe, helpes, elevates, extends it. ${ }^{42}$

Music is closely related to the preservation and restoration of physical and mental well-being, ${ }^{43}$ and thus is frequently employed to alleviate frustration caused by thoughts of love. In Thomas Heywood's $A$ Challenge for Beauty (c 1635), ${ }^{44}$ the aristocratic lady Hellena demands that her maid sing a song to relieve her love-troubled mind: 'lets have a song Rosara: I would have the subject love, and yet modest to, and yet a little wanton, yet chast and innocent as dreams of coles' (3.1, p.37). Hellena's rather unusual description of a desired type of music - modest, wanton, chaste, and innocent - again validates music's intrinsic duality. Likewise, in Middleton's A Chaste Maid in Cheapside (1613), ${ }^{45}$ when Moll is seriously dispirited by unrequited love and says that 'It is no doctor's art can cure my grief' (5.2.30), her mother suggests that she 'Sing but a strain or two' which will 'revive [her] spirits' (5.2.33-4). In Ben Jonson's The Sad Shepherd (unacted), ${ }^{46}$ Karolin is asked to sing to 'Helpe to divert [the] Phant'sie' (1.5.64) in Aeglamour who has gone mad because of his beloved's supposed death. One other example showing the healing power of music can be found in Fletcher's The Mad Lover $(1617)^{47}$ where Memnon, the title character, has his madness lifted during the course of the play because appropriate music is eventually given to his afflicted mind. ${ }^{48}$

The last few examples have demonstrated how closely music is related to the preservation and restoration of physical and mental well-being, for which 
Merrythought's musical personality and outlook on life make him a most suitable spokesperson.

\section{Merrythought's Songs}

Among the many musical characters present in Jacobean city comedies as well as the broader canon of English Renaissance drama, Merrythought is undoubtedly one of the most full and vivid examples of how characterization can be conducted via constant singing. He bursts into singing about thirty-five times in the play. The frequency of this character's vocal display is even greater than that of those whose profession requires them to sing, such as fools, ballad sellers, courtesans, and songsters. ${ }^{49}$ Merrythought sings as spontaneously as people speak. Such a manner of singing is also known as 'impromptu' singing. ${ }^{50}$ What he sings, be it complete songs or fragments of songs, is an

eclectic mixture of popular ballad tunes and more courtly songs. ${ }^{51}$ Every time he enters a scene, he sings and announces his own entrance with a musical flourish. Even when he is not physically present on stage in certain scenes, we still hear his singing voice. In the same way that he announces himself into a scene, moreover, Merrythought also marks his exits with vocal flourishes. Conventionally, only the entrances and exits of royalty and nobility are marked by flourishes. Giving himself musical entrances and exits therefore furnishes Merrythought with the identity of a man inherently full of music. It also signifies his subconscious demand for and assertion of his own pomp, dignity, and individuality. The abundance of songs that Beaumont uses to characterize Merrythought follows the contemporary convention that plays written for boy companies tend to contain more musical episodes designed to allow the boy actors to exhibit their musical talents. It suggests that when this city comedy was first performed by the Children of the Revels at the Blackfriars in 1607, the boy actor who played the part of Merrythought must have had a powerful singing voice. Having said this, however, the play was unfortunately not well-received by the contemporary audience who 'for want of judgement, or not understanding the privy marke of Ironie about it ... utterly rejected it. ${ }^{52}$

A character whose life seems to be made up of singing and drinking, Merrythought sings while he drinks, and he sings about drinking and merrymaking so often that it is almost impossible to separate his songs from his drinks, and vice versa. Fragments of songs about drinking include: 'Nose, nose, jolly red nose, And how gave thee this jolly red nose?' (1.349-50); 
'Nutmegs and ginger, cinnamon and cloves, / And they gave thee this jolly red nose' (1.345-55); 'I am three merry men, and three merry men.' (2.445); 'Troll the black bowl to me!' (2.448); 'For Jillian of Berry, she dwells on a hill, / And she hath good beer and ale to sell' (4.352-60). This character and his songs fit into another very common use of music in contemporary theatre apart from the many situations already outlined in the previous section, namely, that songs are used to accompany revelries. They heighten the boisterous energy of partying participants, for example, the raucous catch in the pantry by the merry triumvirate (2.3.70) in Twelfth Night (1601), and the feasting song by the beggars (2.2.167-82) in A Jovial Crew (1641). ${ }^{53}$ Singing is also a much-utilized trademark for idiosyncratic individuals, such as the 'deboised' prisoner Brainsick in The Soddered Citizen (c 1629) ${ }^{54}$ who is described as a persistently-drunk moron who 'doth nothinge but singe, $\&$ drincke, \& drincke $\&$ singe, / And singe \& drincke' (1.1, p.5), and the Welshman Randall from William Rowley's A Match at Midnight (c 1622)55 who is 'the witty man, the pretty man, the singing man, he has the dantiest dittie, so full of pith, so full of spirit' (E3v). Merrythought's frequent singing not only defines him as a character with a distinctive philosophy, but also situates him dramaturgically in this metatheatrical city comedy. So far, critical discussion regarding the play's metatheatrics tends to focus on aspects such as the citizens' verbal interruption of and intervention in the centre-stage actions, or the 'fluid use of space' as presented in Leslie Thomson's recent essay which treats of the playwright's blurring the dividing lines among players, characters, and theatregoers, and has merely a couple of brief remarks about the songs. ${ }^{56}$ The rest of this article will examine how this jolly old man connects and communicates via singing with other characters from both 'The London Merchant' and The Knight of the Burning Pestle, and how he highlights musically the metatheatricality in the play. Due to the number of songs Merrythought has, I will discuss a few selected songs in detail to illustrate the featured qualities of this music-loaded character.

Merrythought's songs accentuate his intrinsic connection to music. He sings more than he drinks or eats. The act of singing is a predicate of all his activities; it is the basis of his mirth. Any victual is subordinate to his singing. Just as people need air to sustain their lives, Merrythought needs songs (airs) to live his life. Merrythought is often seen to be living on the verge of food scarcity. Singing, comically enough, provides for him the sustenance that he needs - as his wife puts it: 'Let him stay at home and sing for his supper' (2.84). He sways onto the stage in act 1 singing 'Nutmegs and ginger', which 
is part of the chorus of a contemporary drinking song, 'Of all the birds that ever I see', in Thomas Ravenscroft's Deuteromelia. ${ }^{57}$ His wife reminds him, 'If you would consider your state, you would have little list to sing, iwis' (1.356-7), to which he replies, 'It should never be considered while it were an estate, if I thought it would spoil my singing' (1.358-9). ${ }^{58}$ The state that he is in - having scanty supply of daily sustenance - deteriorates so quickly with his prodigal enjoyment of 'good meat' and 'good drink' (1.362-3) that by act 4 he has 'Not a denier left' (4.329). He tells his servant boy to forget about not having any drink because he has 'mirth' at home, an utterance that he finishes with a song 'For Jillian of Berry, she dwells on a hill, / And she hath good beer and ale to sell'. He then immediately tells another boy to forget about bread and supper and that they should 'preserve' the mirth and they 'shall never feel hunger' (4.362-3). He puts his philosophy into practice by sharing with the boys a catch 'Ho, ho, nobody at home' (4.365-8) from Ravenscroft's Pammelia. ${ }^{59}$ Music overrides everything in Merrythought's life. Even when his wife leaves him, he still sings: 'Hey-ho, farewell, Nan' (1.4278). On declaring that all he has 'to do in this world is to be merry' (1.432), he leaves the stage singing again, thus ending the first act. At this moment the first interlude is sounded. In fact all acts end with a song from Merrythought, and an interlude follows immediately afterwards in each case (apart from the final act). ${ }^{60}$ Entr' acte music, an alternative label for interlude music, was a new practice adopted at the Blackfriars. ${ }^{61}$ Used in a dramatic work, it signifies the end of the current act while allowing time for any preparation or rearrangement of people and props for the next act. In The Knight of the Burning Pestle, each interlude facilitates the shift from the Merchant plot to the Knight plot. It is worth mentioning that after each interlude begins to play, the on-stage audience of the Merchant plot, George and Nell who belong to the Knight plot, would comment on either the interlude (Int.1, 2; Int.2, 4-10), the interludal dance (Int.1, 5-6; Int.3, 7-10), or Merrythought's singing (Int.1, 1; Int.4, 1). Given the continuity between Merrythought's songs and the instrumental music, the songs work with the interludes in the transition from the Merchant plot to the Knight plot. That Merrythought's songs contribute to the connection of the two plots will be further illustrated in the ensuing examples.

Act 2 sees Merrythought's singing infused with some more of his own philosophy. Similar to act 1, he enters the stage singing and musing about the importance of jocundity: 'To what end should any man be sad in this world?' (2.446); serious puritanical attitude is morbid to him (2.449-54). Not only is 
singing symbolic of goodly mirth, it is also an indicator of honesty to Merrythought: 'Never trust a tailor that does not sing at his work; his mind is of nothing but filching' (2.454-5). ${ }^{62}$ This attracts a concurring exclamation from Nell, which is one of her many metatheatrical utterances:

'tis worth noting. Godfrey, my tailor, ... never sings, and he had fourteen yards to make this gown; and I'll be sworn, Mistress Pennistone, the draper's wife, had one made with twelve.

Another layer of Merrythought's life philosophy with which music is associated is that singing itself is a form of vital nutrient that keeps one healthy and wholesome:

'Tis mirth that fills the veins with blood, More then wine, or sleep, or food.

Let each man keep his heart at ease;

No man dies of that disease.

He that would his body keep

From diseases must not weep,

But whoever laughs and sings

Never he his body brings

Into fevers, gouts, or rheums,

Or ling'ringly his lungs consumes,

Or meets with achès in the bone,

Or catharrhs or griping stone,

But contented lives for aye,

The more he laughs, the more he may.

This signature song about mirth and health, generally regarded as a quality composition designed specifically for the play, ${ }^{63}$ appears as a sonnet entitled 'An Invitation to Mirth' in The Academy of Pleasure: ${ }^{64}$

HE that's contented lives for aye,

The more he laughs the more he may,

Nere meets with Acher in the bone,

O Catharres, or griping stone,

O lingringly his Lungs consumes

Into Feavers, Gouts, or Rhumes, 
Never he his body brings,

Cause he ever laughs and sings,

He that would his body keep

From Diseases must not weep,

Let each man keep his heart at ease,

No man dies of that disease,

Tis Mirth that fills the veins with blood

More than wine, or sleep, or food.

The lines in the sonnet are rearranged in such manner that the final couplet of the original song is placed at the beginning and almost all subsequent lines, with syntactic alterations, are arranged in a reverse order of the original design. The discrepancies from the original composition suggest either mnemonic or technical inaccuracies made by transcribers or compositors during the preparation of the conduct book, or deliberate rearrangement so that the new version could then be passed on as a new poem and be included in a widely-circulated book. ${ }^{65}$ Either way, it shows the significance of the song's message about music, mirth, and health. ${ }^{66}$

In addition to serving as an expression of personal beliefs, music is used as a means of interaction, as is presented towards the end of act 2 . When confronted by the anxious Merchant Venturewell in search of her daughter who has eloped with Jasper, Merrythought's son, Merrythought simply continues to vocalize his carefree outlook on life. He reacts to Venturewell's agitation with inappropriate and dismissive songs. His musical mockery serves as a highly dramatic contrast to the merchant's frustration.

Merchant Venturewell rushes in when Merrythought is singing an opening quatrain of a popular ballad 'Walsingham'. ${ }^{67} \mathrm{He}$ entreats Merrythought not to sing: 'This mirth becomes you not' (2.486), but the old man merely snaps with a fragment from another popular song 'Why, an if she be, what care I?' (2.487-8). This fragment is a variant of the last stanza of 'Farewell, dear love'. ${ }^{68}$ The distraught Venturewell protests against Merrythought's 'what care I' mockery and blames Jasper for stealing his daughter away. Merrythought makes fun of his apprehension with a balladic fragment which tells of how a man steals away a lady on a horse. ${ }^{69}$ Despite Venturewell's distressed imploration and threat of hunting Jasper down, Merrythought derides him further. Interspersed in his advice to the merchant, 'Think no more on her, but sing loud' (2.500-1), are three more nonchalant fragments of songs, and because Venturewell's talk of his daughter 'spoils [Merrythought's] mirth' (2.519-20), 
the old man eventually blocks it out with an adapted version of yet another contemporary ballad that narrates the legendary story of Sir Guy of Warwick (Figure 1). ${ }^{70}$ This energetic song, most probably performed vivace, pushes the old man's vocal spirit to a high point. The song contains short, catchy phrases. The same rhythmic pattern is heard four times virtually consecutively, with typical refrain interjections such as 'Down, down' and 'De derry down' inserted at the end of every six beats, that is, after the words 'sake' (bar 2), 'Guy' (bar 4), 'bright' (bar 6), and 'eye' (bar 8). Also, all these four phrases begin with an identical arpeggio pattern: $\mathrm{F}^{5}-\mathrm{A}^{5}-\mathrm{C}^{6}-\mathrm{F}^{6}$. This recurrence of harmonic pattern every two bars gives the melody a staccato jolt as well as a bright tone overall, thus investing in the singer a soaring triumph. All the merchant can do is to leave Merrythought, vowing to avenge himself (2.530).

In act 3, Merrythought continues to assert the vital importance of music in his personal life. The old man incorporates singing into his interaction with other people at a higher level of dramaturgical complexity. Not only does he turn away his wife with songs, he also sings across from the Merchant plot to the Knight plot, apparently targeting Nell. The play thus further exposes the inherent link between him and his music. More often than not, whenever music is heard in this play Merrythought can be expected to be seen or heard. When Mistress Merrythought appears with her son, Michael, outside the Merrythought household after having lost all their money, music is sounded from 'within' (sd 3.483) and the wife identifies it with her husband: 'Hark, hey dogs, hey, this is the old world, i'faith, with my husband' (3.483-4). Not surprisingly Merrythought is then heard singing from 'within' (sd 3.488) about his merry-making: 'If you will sing and dance and laugh ... We shall be merry within this hour' (3.488-92). The old man is not yet visible on stage at this moment according to the stage direction, but he defines his role and place in the theatre through making himself heard. The way he asserts his individual position and voice without speaking much is especially effective in

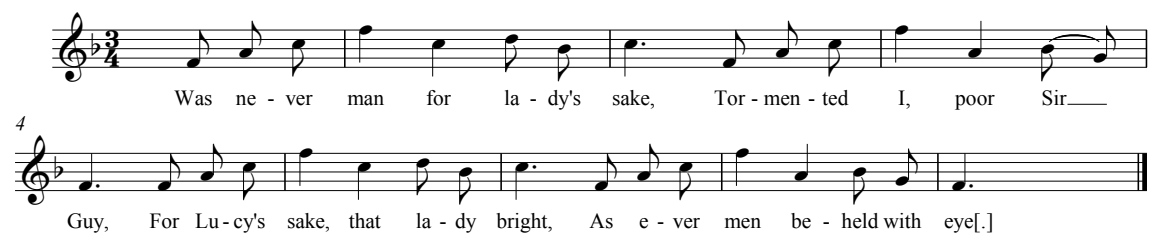

Fig. 1. Courtesy of The Revels Plays and Manchester University Press. 
that even if he is visually absent, or semi-absent when he can be partially seen at the window later in the scene (3.503), his singing voice is always present. He maintains his power and right as an inhabitant of the house and manages to stay as the centre of attention not only in the Merchant plot but also of the Knight plot. That he is partially seen at the window in act 3 is very telling. His action of singing behind a window detaches him from the world of verbal exchange. Such detachment is embedded in his name Merrythought: he is merry in his thoughts, in his secluded musical world. Being thus positioned, he further establishes his identity primarily as a singing voice.

Music repeatedly proves to be the focal point of Merrythought's life. The attitude that he holds towards dealing with people is the same as that towards drinks: better to be without drink than to drink without music, better to be without company than to be in the company of people without music. He makes it clear that anyone entering his house — his extended identity - should be ready to sing. In other words, singing is an aural key that verifies one's right of entry into the Merrythought household. One of the most comical scenes involving musical admittance is when the estranged Mistress Merrythought, having her son Michael with her, demands that Merrythought open the door and let them in. They are, however, not allowed into the house until they do what Merrythought says, that is, to sing. Merrythought commands his wife to sing as a reconciliatory gesture before letting her back into the house (3.567-8). When she refuses to do so, he rejects her and bids her to 'Go from my window, love, go' (3.503), and tells her that she 'cannot be lodgèd' (3.507) in his house (Figure 2). Merrythought sings two stanzas, 'Go from my window' (3.503-7) and 'Begone, begone, my Juggy, my puggy' (3.522-6), both of which come from the same ballad licensed as 'Go from my window' in $1588 .^{71}$ This ballad tune was very popular during the Elizabethan and Jacobean periods. It is present in several contemporary plays such as Thomas Dekker's Blurt, Master-Constable (c 1601-2) ) $^{72}$ in which Simperina, a maid of the courtesan Imperia, sings 'Go from my window'

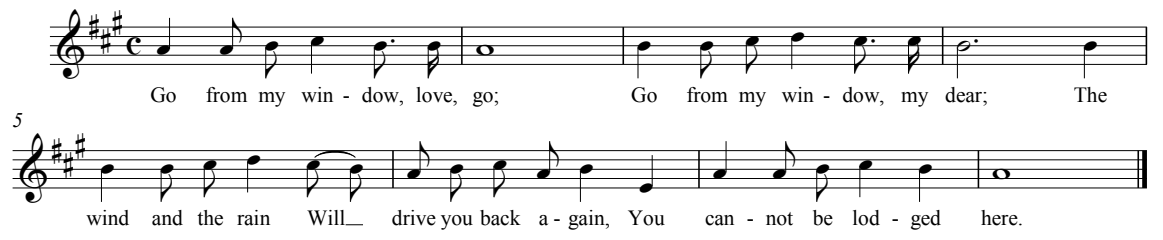

Fig. 2. Courtesy of The Revels Plays and Manchester University Press. 
$\left(\mathrm{F} 2^{\mathrm{v}}\right)$ to turn away an unwelcome client, Fletcher's Monsieur Thomas where a maid sings 'Come up to my window' (3.3.81-5) flirtatiously to Monsieur Thomas shortly prior to his falling off from the window and breaking his leg, and Heywood's The Rape of Lucrece, which contains an expanded version of Merrythought's stanza 'Begone, begone'. ${ }^{73}$ The wide use of this tune in such plays may be attributed to the simplicity and adaptability of the lyrics (be it bidding someone to go away or beckoning them to approach), as well as the steady tunefulness of the melody. This melody in a major key is designed to be sung in a well-paced andante $4 / 4$ time. $^{74}$ It starts with two short declarative phrases which are a pair of sequence, followed by two bars made up of mainly quavers which gives the musical phrase a forward drive, and ends with a final statement that 'You cannot be lodgèd here'. The uncomplicated rhythm and the middle register facilitate the articulation of words. Such arrangement of a warm melody, which sounds welcoming on its own, coupled with words of refusal and rejection creates an ironic tone, whether the singer performs it seriously or light-heartedly, perhaps even more so when sung light-heartedly. The rendition of the first stanza is followed by Merrythought's justification of his enjoyment of singing and merriment. When his wife protests against his scorn (3.517), he bids her 'Begone', sings one more verse to the same melody, and calls for 'light music and more wine' (3.527).

Having witnessed the above exchange between the Merrythoughts, Nell disapproves of Merrythought's treatment of his wife: 'he's an ingrant old man to use his bedfellow so scurvily' (3.530-1). She calls out to Merrythought, trying to engage him in a dialogue: 'D'ye hear, Master Merrythought, may I crave a word with you?' (3.539-40). What ensues can be regarded as a dialogue between the citizen's wife and Merrythought, in which Merrythought, in his usual self, sings a verse as a retaliation to his on-stage audience's didacticism:

Wife. I had not thought, in truth, Master Merrythought, that a man of your age and discretion, as I may say, being a gentleman, and therefore known by your gentle conditions, could have used so little respect to the weakness of his wife. For your wife is your own flesh, the staff of your age, your yoke-fellow, with whose help you draw through the mire of this transitory world. Nay, she's your own rib. And againe-

Old Merrythought. (Within) I come not hither for thee to teach, 
I have no pulpit for thee to preach,

I would thou hadst kissed me under the breech,

As thou art a Lady gay.

Merrythought's song contains words deliberately aimed at retorting Nell's accusatory remark. He concludes his vocal rebuttal with a rude 'I would thou hadst kissed me under the breech'. Nell finds the old man most offensive. She exclaims, 'Give me such words that am a gentlewoman born! Hang him, hoary rascal!' (3.558-9). Later still, in act 4, she complains about Merrythought's ill manner: 'You heard him take me up like a flirt-gill, and sing bawdy songs upon me' (4.19-20). The exchange between Merrythought and the citizen's wife in act 3 shows that Merrythought's musical response to his on-stage audience has brought him further than the centre-stage action, and that the citizen's wife has crossed over the virtual fence between the centrestage action and the on-stage audience.

The domestic conflict of the Merrythoughts is resolved in act 5 when Mistress Merrythought gives in to her husband's command:

Old Merrythought. … you shall sing before you enter; therefore, dispatch your song and so come in.

Mrs Merrythought. [Within] Well, you must have your will, when all's done. - Mick, what song canst thou sing, boy?

Michael. [Within] I can sing none, forsooth, but 'A Lady's Daughter of Paris' properly.

And hence the mother and the son sing 'It was a lady's daughter' (5.229). What they sing is a staunch Protestant song about a young lady defying her mother's command to attend the Mass. ${ }^{75}$ The subject matter of the song is evidently incongruous with the situation the mother and the son are in, so it goes well with Michael's reason for coming up with this particular song: 'I can sing none, forsooth, but "A Lady's Daughter of Paris" properly' (5.228). As soon as Merrythought hears them sing, he opens the door and welcomes home his wife and his son.

Having granted entrance to those who comply with his musical request, Merrythought has one more visitor awaiting to be admitted. When Merchant Venturewell asks to be seen, Merrythought insists that the merchant sing:

Merchant. [Within] Are you within, sir? Master Merrythought! 
Old Merrythought. What are you? Are you merry? You must be very merry if you enter.

Merchant. [Within] I am, sir.

Old Merrythought. Sing, then.

Merchant. [Within] Nay, good sir, open to me.

Old Merriyhought. Sing, I say, or, by the merry heart, you come not in. Marchant. [Within] Well, sir, I'll sing:

Fortune my Foe, orc.

[Old Merrythought admits Merchant.]

Old Merrythought. You are welcome, sir; you are welcome. (5.234-46)

The tune of 'Fortune my foe' (Figure 3) was very popular in Renaissance England. A large number of songs and contemporary ballads about crimes and executions of criminals are documented to have been sung to this tune. ${ }^{76}$ This same tune also appears in many Renaissance plays as a song episode. ${ }^{77}$ It must have been easily recognized by the contemporary theatrical audience. That a character would sing such a gallows song might seem rather odd in a comedy, and the more stanzas the actor would opt to sing, the funnier it would seem. ${ }^{78}$ The audience could have been taken aback upon hearing this morbid song about punishment and death. Also, the apparent inappropriateness of the song may render Venturewell's singing comical as he is desperate to speak to Merrythought and he is promised admittance as long as he sings something. To say that the merchant's choice of song is completely out of context is not fair either, however. Before he comes to Merrythought's house, the merchant has been visited by Jasper disguised as a 'wand'ring spirit' (5.255) who tells him that Luce, his daughter, 'is quite borne away / On wings of angels through the liquid air / To far out of [his] reach' (5.10-12) and that he should repent and make amends with Merrythought (5.32). Believing that Luce is gone forever, the merchant repents his cruelty in for-

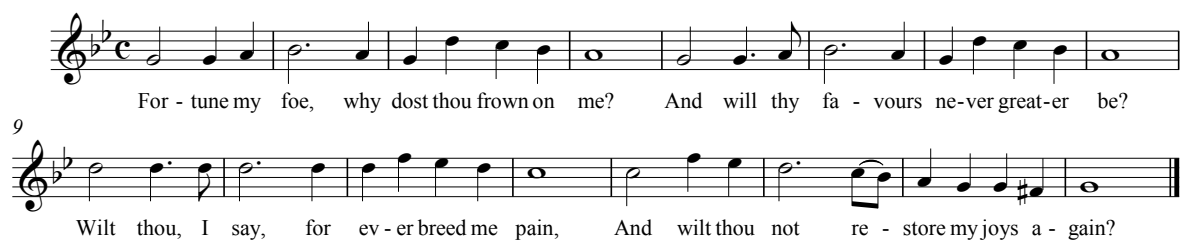

Fig. 3. Courtesy of The Revels Plays and Manchester University Press. 
cing Jasper and Luce apart, and he comes to Merrythought 'to ask for forgiveness' (5.249-50). Burdened with a guilty conscience, he compares himself to a criminal sentenced to death and starts singing a gallows song. The minor tonality of the melody sets a heavy and solemn mood for the song. The first two phrases are identical, both ending on a rhetorical question of plea. The third phrase occupies the highest register of the song, signifying a loud cry for mercy. The melody ends with a descending minor scale which creates a vocal effect of humbling oneself in front of the listener. The merchant is received by Merrythought once he finishes singing. This song of repentance once again confirms the validity of Merrythought's logic that music represents all the goodness in personal integrity. Hence, admitting only those who sing guarantees the presence of virtue in his household. Indeed, the merchant sheds his condescending pride, shows his humility through both vocal and verbal display of his remorse, and becomes an eligible participant in the Merrythought household.

The final song in this city comedy is believed to be another one specifically designed for the play because it is 'so much à propos and so much in the ... manner of contemporary lyric'. ${ }^{79}$ It echoes Merrythought's song about mirth in act 2 and sums up his philosophy: happiness is what is ultimately important in his life, and to achieve happiness one needs to have music.

Better music ne'er was known
Than a choir of hearts in one.
Let each other that hath been
Troubled with the gall or spleen,
Learn of us to keep his brow
Smooth and plain as ours are now.
Sing, though before the hour of dying;
He shall rise, and then be crying,
'Hey, ho, 'tis nought but mirth
That keeps the body from the earth.'

The song repeats the importance of keeping one's eyebrows smooth and the effects of singing in maintaining one's health and vitality. The old man introduces this song as a proposal for everyone in the story of 'The London Merchant' to sing: 'Methinks all we, thus kindly and unexpectedly reconciled, should not depart without a song' (5.344-5). So the final chorus, 'a choir of hearts in one', shows that somehow Merrythought has infected those around 
him with his love for music and mirth. Not only is singing a vital propellant in this old merry character, it is also a reconciliatory and uniting force for everyone in the Merchant plot. This chorus, the only group song in the play, is sung in the Merrythought household. It can also function as a conclusion to all the previous episodes in which characters are asked to sing before they can be admitted into Merrythought's home. Music as the extended identity of Merrythought is yet again authenticated.

Merrythought sings more than he speaks. His singing accounts for more than 140 lines, which is about twenty lines in surplus of his speech. His singing serves several dramaturgical functions. It informs us of his mirth-oriented outlook on life. His mirth and health do not need the support of money, drink, or even food; music alone will suffice. Therefore his singing establishes him as a representation of everything non-mercenary in this city comedy, which aims to satirize the mercantile values of the society. Besides, Merrythought's musical interaction with other characters attracts metatheatrical comments from the on-stage audience Nell. Sometimes her comments stay within the Knight plot, such as telling her husband her opinions about Merrythought and his songs ('It's a foolish old man this, is not he, George?' [1.374], 'I'll be sworn he's a merry old gentleman' [Int. 1, 1], 'This old fornicating fellow will not out of my mind yet' [Int. 3, 3]). Other times they are transmitted across the boundary between the two plots such as her exchange with Merrythought in act 3. The merry old man's songs certainly form one indispensible component of the metatheatrics of this city comedy, while accommodating an expression of the contemporary belief in music's duality.

\section{Notes}

1 Francis Beaumont, The Knight of the Burning Pestle, ed. Sheldon P. Zitner, The Revels Plays (Manchester, 1984), 2.84-5, hereafter referred to as KBP, Zitner (ed.).

2 First performance dates of plays are given in parentheses after the initial references. This information is provided with reference to the 'Chronological table' in A.R. Braunmuller and Michael Hattaway (eds), The Cambridge Companion to English Renaissance Drama (Cambridge, 2003), 420-47.

3 A detailed evaluation of each pair of dichotomy has been given in Katrine K. Wong, 'Theatrical Aspects and Meanings of Music in English Renaissance Drama' (PhD thesis, University of Leeds, 2008). The present article is an expansion based on the section 'Merrythought'. 
4 No examples of 'entr'acte' music (interact music) and music for dumb shows and masques are given here due to the fairly consistent functions that each serves: the former provides background music and sets the atmosphere during changes of scenes or trimmings of candles in private theatres, the latter supplies musical accompaniment. For discussions of 'entr'acte' music and musical accompaniment in dance, dumb shows, and masques see Linda Austern, Music in English Children's Drama of the Later Renaissance (Amsterdam, 1992).

5 Plato, The Republic, ed. G.R.F. Ferrari, trans. Tom Griffith (Cambridge, 2000), 411b-c.

6 Aristotle, The Politics, ed. Stephen Everson (Cambridge, 1988), 1337b23. The other three branches are reading and writing, gymnastic exercises, and drawing.

7 Boethius, 'from Fundamentals of Music', Source Readings in Music History, ed. Oliver Strunk, rev. Leo Treitler (New York, 1998), 138.

8 Isidore of Seville, 'from The Etymologiarum', in Source Readings in Music History, 150. See also David Lindley, Shakespeare and Music (London, 2005; rpt. 2007), 15-25, for a summary of the analogy between music and heavenly order and bodily concord in the human body.

9 Gioseffo Zarlino, 'from Institutioni harmoniche', in Source Readings in Music History, 297.

10 Thomas Wright, The Passions of the Minde in Generall, ed. Thomas O. Sloan (Urbana, 1971), 171.

11 The praise of musicke (Oxford, 1586), 58.

12 William Byrd, Psalmes, sonets, and songs of sadnes and pietie (London, 1588), A3v.

13 Frederick William Sternfeld, Music in Shakespearean Tragedy (London, 1963), 54.

14 Henry Peacham, The Compleat Gentleman (London, 1622), O4v.

15 Philip Stubbes, The anatomie of abuses (London, 1583), R4v-S1.

16 Stephen Gosson, The schoole of abuse (London, 1579), B3. For more comparative studies of the issue of the moral bipolarity in music related to the female gender, see Julia Craig-McFeely, 'The Signifying Serpent: Seduction by Cultural Stereotype in Seventeenth-Century England', Linda Phyllis Austern (ed.) Music, Sensation, and Sensuality (New York, 2002), 299-317; Leslie C. Dunn, 'Ophelia's Songs in Hamlet: Music, Madness, and the Feminine', Leslie C. Dunn and Nancy A. Jones (eds) Embodied Voices: Representing Female Vocality in Western Culture (Cambridge, 1994), 50-64; Linda Austern's articles "'Alluring the Auditorie to Effeminacie": Music and the Idea of the Feminine in Early Modern England', Music \& Letters 74 (1993), 343-54, and "'Sing Againe Syren": The Female Musician and Sexual Enchantment in Elizabethan Life and Literature', Renaissance Quarterly 42 (1989), 420-48.

17 For more discussion specific to music during the Renaissance period, see Lorenzo Bianconi, Music in the Seventeenth Century, trans. David Bryant (Cambridge, 1987); 
Frederick Binkerd Artz, From the Renaissance to Romanticism: Trends in Style in Art, Literature, and Music 1300-1830 (Chicago, 1962); Morrison Comegys Boyd, Elizabethan Music and Musical Criticism (Philadelphia, 1962); Gretchen L. Finney, Musical Backgrounds for English Literature: 1580-1650 (New Brunswick, 1962); John Hollander, The Untuning of the Sky: Ideas of Music in English Poetry, 1500-1700 (Princeton, 1961).

18 George Walton Williams (ed.), Fredson Bowers (gen. ed.), The Dramatic Works in the Beaumont and Fletcher Canon, 10 vols (Cambridge, 1966-96), 9.221-321.

19 Beaumont and Fletcher, 9.569-669.

20 Katrine Wong, "A damnd divel, or an Angel?" - Songs in The Maid in the Mill, paper presented at the annual international symposium for the Perth Medieval and Renaissance Group, Perth, Australia, August, 2006.

21 Beaumont and Fletcher, 4.261-414.

22 Ben Jonson, Volpone, ed. R.B. Parker (Manchester, 1983).

23 Beaumont and Fletcher, 4.415-540.

24 Beaumont and Fletcher, 3.1-111.

25 The Plays and Poems of Philip Massinger, Philip Edwards and Colin Gibson (eds), 5 vols (Oxford, 1976), 2.1-96.

26 'Soft music' is commonly used in English Renaissance drama as a collective term indicating the use of viols with or without lute, and perhaps recorder too. For possible arrangements of 'soft music' and 'loud music', see John Manifold, 'Theatre Music in the Sixteenth and Seventeenth Centuries', Music \& Letters 29 (1948), 383-8, and Peter Walls, Music in English Courtly Masque, 1604-1640 (Oxford, 1996), 152-3.

27 Fredson Bowers (ed.), The Complete Works of Christopher Marlowe, 2 vols (Cambridge, 1981), 1.149-252.

28 The Dramatic Works of Thomas Heywood (ne), 6 vols (New York, 1964), 3.347-431.

29 Plato, Republic, 398e-399c.

30 Lodowick Lloyd, The pilgrimage of princes (London, 1573), 2 F3.

31 This is the stage direction used in both Comedies and tragedies written by Francis Beaumont and John Fletcher (London, 1647) and Fifty comedies and tragedies written by Francis Beaumont and John Fletcher, Gentlemen; all in one volume, published by the authors original copies, the songs to each play being added (London, 1679). Bowers's edition has it abbreviated to 'With a Banket prepard, with Hoboies'.

32 Ben Jonson, Poetaster, ed. Tom Cain (Manchester, 1995).

33 G. Blakemore Evans (ed.), The Riverside Shakespeare (Boston, 1974), 1479-516. Unless otherwise noted, all quotations from Shakespeare's plays will be taken from this edition.

34 See footnote to 'still' (3.2.90) in Pericles, ed. F.D. Hoeniger (London, 1963). 
35 See footnote to 'rough ... music' (3.2.87) in Pericles, ed. Suzanne Gossett (London, 2004). Del Vecchio and Hammond make a note of keeping the word 'rough' in the 1998 Cambridge edition. They cite Burton's Anatomy of Melancholy for the claim that music 'is a most forcible medicine ... to revive the languishing soul ... affecting not only the ears, but the very arteries, the vital and animal spirits, it erects the mind'. See supplementary note to 3.2.85-6 for an editorial discussion of choosing between 'rough' and 'still' in Doreen Del Vecchio and Antony Hammond (eds), Pericles (Cambridge, 1998), 195.

36 See Penelope Gouk, 'Sister Disciplines? Music and Medicine in Historical Perspective', in Penelope Gouk (ed.), Musical Healing in Cultural Contexts (Aldershot, 2000), 171-96.

37 The Riverside Shakespeare adopts the Q4 spelling.

38 See footnote to 'viol' (3.2.89) in Pericles, Gossett (ed.).

39 See Donald A. Beecher and Massimo Ciavolella, 'Love Melancholy as a Medical Idea in the Ancient World' and 'Erotic Melancholy and Medieval Medicine', in Jacques Ferrand, A Treatise on Lovesickness, ed. and trans. Donald A. Beecher and Massimo Ciavolella (New York, 1990).

40 Ibid, 65. See also Gouk, Musical Healing, for detailed discussion of different forms of medicinal use of music.

41 Ferrand, A Treatise on Lovesickness, 67. Jaques from Shakespeare's As You Like It (c 1599) gives a most vivid example of feeding one's melancholy with music. Having listened to 'Under the Greenwood Tree' sung by Amiens, Jaques asks the singer to give him more music: 'More, I prithee more. I can suck melancholy out of a song as a weasel sucks eggs' (2.5.11-12).

42 Robert Burton, Anatomy of Melancholy, Thomas C. Faulkner, Nicolas K. Kiessling, and Rhonda L. Blair (eds), 3 vols (Oxford, 1989-2000), 2.113-4 (2.2.6.3). The section 'Musicke a Remedy' contains a collection of quotations from other thinkers.

43 See Burton's analogy of music and mirth in Anatomy of Melancholy 2.116-24 (2.2.6.4).

44 Heywood, 5.1-79.

45 Linda Woodbridge (ed.), Gary Taylor and John Lavagnino (gen. eds), Thomas Middleton: The Collected Works (Oxford, 2007), 907-58.

46 C.H. Herford and Percy Simpson (eds), Ben Jonson, 11 vols (Oxford, 1925-52), 7.1-49.

47 Beaumont and Fletcher, 5.1-149.

48 Katrine Wong, "“Much taken / He has bin with thy battell songs": Music and Masculinity in John Fletcher's The Mad Lover', paper presented at the international conference for the Society for Renaissance Studies, Dublin, Ireland, July, 2008. 
49 Even Valerius from Thomas Heywood's The Rape of Lucrece (c 1607) is hardly a match for Merrythought. Valerius is a stateman-turned-ballater, who sings for his fellow statesmen a total of 19 songs of diverse subject matters (The Rape of Lucrece [London, 1638]).

50 The opposite of 'impromptu' singing is 'performative' singing. We tend to take impromptu songs to be a direct and unrehearsed expression of character, whereas we view performative songs as in part a kind of concert-hall experience. See also Lindley, Shakespeare and Music, 141-2.

51 See KBP, Zitner (ed.), 173-83.

52 See Walter Burre, preface to The Knight of the Burning Pestle (London, 1613), A2. The play was not revived until 1635 by Queen Henrietta Maria's Men. See also Lucy Munro, 'The Knight of the Burning Pestle and Generic Experimentation', Garrett A. Sullivan Jr, Patrick Cheney, and Andrew Hadfield (eds), Early Modern English Drama: A Critical Companion (Oxford, 2006), 189-99.

53 Richard Brome, A Jovial Crew, ed. Ann Haaker (London, 1968).

54 John Clavell, The Soddered Citizen (London, 1936). The play was believed to have been first published in 1653 (see textual introduction in The Soddered Citizen, v). It used to be attributed to Shackerley Marmion, but the author is now generally considered to be John Clavell.

55 William Rowley, $A$ match at midnight (London, 1633).

56 See Leslie Thomson, “Who's In, Who's Out?": The Knight of the Burning Pestle on the Blackfriars Stage', in Paul Menzer (ed.), Inside Shakespeare: Essays on the Blackfriars Stage (Selingrove, 2006), 61-71. See also Tiffany Stern, 'Taking Part: Actors and Audience on Stage at Blackfriars', Inside Shakespeare, 35-53.

57 Thomas Ravenscroft, Deuteromelia (London, 1609), C2v-C3.

58 Another member of the household also tells Merrythought that it is not appropriate to sing given the occasion. The servant boy, who brings in a coffin which he believes to be containing Jasper's body, says to Merrythought: 'if you knew what I have brought you, you would have little list to sing' (5.179-80).

59 Thomas Ravenscroft, Pammelia (London, 1609), G1.

60 There is a slight delay of Interlude 3 (if one holds this observation strictly) because act 3 ends with Mistress Merrythought making a resentful speech (3.572-80) after having been denied entry into the Merrythought household by Merrythought's snatch (3.569-70).

61 For discussion of the use of instrumental music in this play, see KBP, Zitner (ed.), 170-7, and Austern, Music in English Children's Drama, 86-8. 
62 A similar view is found expressed more philosophically by Lorenzo in The Merchant of Venice: 'The man that hath no music in himself ... Let no such man be trusted' (5.1.82, 88).

63 See KBP, Zitner (ed.), 174, and Critical Introduction to The Knight of the Burning Pestle, ed. Andrew Gurr (Berkeley and Los Angeles, 1968), 7, hereafter referred to as KBP, Gurr (ed.).

64 The Academy of Pleasures (London, 1656), E5.

65 The inclusion of an appendix 'Containing An Alphabeticall Explanation of Hard Words, For Instruction of the Weaker sort of Capacities' (The Academy of Pleasures, G5-G9) is evidence for a wide readership.

66 The connection between music and health is described on 9-11.

67 Ophelia sings 'How should I your true love know' to the tune of 'Walsingham' (4.5.23-6, 29-32, 36, 38-40) in Hamlet (c 1600).

68 The song 'Farewell, dear love', collected in Robert Jones, The first booke of songes \& ayres (London, 1600), is shared by Sir Toby, Feste, and Sir Andrew (2.3.101-10) in Twelfth Night.

69 The lyrics are believed to have come from either 'The Ballad of the Knight and the Shepherd's Daughter' or 'The Douglas Tragedy'. See KBP, Zitner (ed.), 179.

70 Corresponding lyrics have been inserted into the tune identified. See KBP, Zitner (ed.), 179-80. Examples of musical tunes are reproduced from those identified in KBP, Zitner (ed.).

71 KBP, Zitner (ed.), 181.

72 Thomas Dekker, Blurt, Master-Constable (London, 1602).

73 In all early printed texts starting from the 1614 quarto, the song 'Arise, arise my Juggie my Puggie' of thirty-two lines is inserted at the end of the play as one of the 'songs, which were added by the stranger that lately acted Valerius' (Thomas Heywood, The Rape of Lucrece [London, 1614], K2).

74 Gurr also suggests it be sung in a slow tempo. See KBP, Gurr (ed.), 8.

75 KBP, Zitner (ed.), 182.

76 Here are a few examples: 'An excellent song wherein you shall finde great consolation for a troubled minde' (London, 1628); 'The godly end, and wofull lamentation of one John Stevens a youth that was hang'd, drawne, and quartered for high-treason, at Salisbury in Wilshire, upon Thursday being the seventh day of March last 1632' (London, 1633); '[The] complaint and lamentation of Mistresse Arden of [Fev]ersham in Kent who for the love of one Mosbie, hired certaine ruffians and villaines most cruelly to murder her husband: with the fatall end of her and her associats' (London, 1633); 'A cruell murther committed lately upon the body of Abraham Gearsy who liv'd in the Parish of Westmill, in the County of Harford; by one Robert Reeve, and 
Richard Reeve, both of the same Parish: for which fact Robert was prest to death, ... Richard was hang'd; and after both of them were hang'd up in chaines, where now they doe remaine, to the affrightment of all beholders' (London, 1635); 'The lamentation of Master Pages wife of Plimmouth who being enforced by her parents to wed him against her will, did most wickedly consent to his murther, for the love of George Strangwidge; for which fact she suffered death at Barstable in Devonshire. Written with her owne hand a little before her death' (London, 1635).

77 To name but a few: Jucolo has the song in The Maydes Metamorphosis (c 1600; London, 1600), C3v; Graccus is given the tune in (possibly Lewis Machin's) Everie Woman in Her Humor (c 1607; London, 1609), G3; Fred sings it in John Cumber's The Two Merry Milke-Maids, or, The Best Words Weare the Garland (c 1619; London, 1620), H3v; Master Joylesse whistles the tune in Richard Brome's The Antipodes (c 1638; London, 1640), G1. It is also mentioned in dramatic works such as Ben Jonson's The Case is Altered, 4.8.74 (Ben Jonson, 3.93-190); James Shirley's The Gratefull Servant (1629; London, 1630), K2v; William D'Avenant's Love and Honour (1634; London, 1649), B1.

78 Gurr notes that 'It is a very long ballad, twenty-two stanzas to a slow and mournful tune, of which perhaps only the first few stanzas were sung'. See KBP, Gurr (ed.), 104.

79 KBP, Zitner (ed.), 174. 